УДК 616.24-002.5(100)

DOI 10.11603/2411-1597.2019.3.10675

\title{
ТУБЕРКУЛЬОЗ ЛЕГЕНЬ ЯК ГЛОБАЛЬНА ПРОБЛЕМА УСЬОГО СВІТУ
}

\author{
К. В. Жавріченко \\ Костянтинівський медичний коледж \\ Тернопільський національний медичний університет \\ імені І. Я. Горбачевського МОЗ Украӥни
}

У статті проаналізовано причини розповсюдження туберкульозу в Україні та за ї̈ межами, а також фактори, що спричиняють виникнення цього захворювання.

\section{PULMONARY TUBERCULOSIS AS A GLOBAL PROBLEM OF THE WORLD}

\author{
K. V. Zhavrichenko \\ Konstantyniv Medical College, \\ I. Horbachevsky Ternopil National Medical University
}

The article analyzes the causes of high incidence rates of tuberculosis in Ukraine and abroad, as well as the factors that cause the disease.

Вступ. Актуальність проблеми туберкульозу для сучасної медицини полягає у значному поширенні захворювання, ранньому розвитку тяжких ускладнень і смерті внаслідок них. На сьогодні туберкульоз (ТБ) $є$ актуальною медико-соціальною проблемою не тільки в Україні, а й в усьому світі. Згідно зі світовою статистикою, щорік в усьому світі від туберкульозу помирає 2 млн людей. За оцінками ВООЗ у період між 2000 і 2020 роками, майже один мільярд людей буде інфіковано, 200 млн захворіє та 35 млн помре від туберкульозу, якщо контроль за епідемією не буде посилено. Ситуація з туберкульозом в Україні дуже складна - з початку 1995 р. зареєстровано епідемію туберкульозу, яка невпинно прогресує та набуває загрозливих масштабів. Щороку помирає від цієї недуги 10-11 тис. хворих, що становить більше 30 осіб в день. У 1995 р. ВООЗ зафіксувала в Україні епідемію туберкульозу, оскільки кількість хворих перевищувала 1 \%. Епідемія невпинно прогресує й набуває загрозливих масштабів. Статистика свідчить про те, що в Україні щоденно реєструють 82 нових хворих на туберкульоз, а 30 - помирає. Туберкульоз на сьогодні - це вже не хвороба маргіналізованих верств населення, а небезпека, яка стосується кожного. За оцінкою ВООЗ, епідемія ТБ в Україні розпочалася з 1995 р. Зростан-

(c) К. В. Жавріченко, 2019 ня захворюваності на ТБ, що спостерігали в країні $з$ 1998 р., зупинено в 2004 р. завдяки централізованим скоординованим заходам уряду, які включали початок фінансування постачання протитуберкульозних препаратів у 2000 р. і запуск першої національної програми лікування туберкульозу в 2002 р., у результаті чого з 2007 р. показники захворюваності було знижено [1]. За даними ВООЗ, в Україні поширеність і захворюваність на ТБ із 2007 р. мають тенденцію до зниження щороку в середньому на 4,4 і 3,3 \% відповідно. У 2014 р. Україна вперше ввійшла і досі перебуває серед п'яти країн світу з найвищим тягарем мультирезистентного туберкульозу (надалі - МР ТБ). Результат успішного лікування МР ТБ - один із найнижчих в Європейському регіоні та становить $46 \%$.

Основна частина. Туберкульоз - це інфекційне захворювання, викликане кислотостійкими мікобактеріями з групи Mycobacterium tuberculosis complexM. tuberculosis, M. bovis i M. africanum. Патомеханізм інфекційного процесу: вдихання мікобактерій $\rightarrow$ фагоцитоз макрофагами $\rightarrow$ розмноження всередині макрофага $\rightarrow$ розпад макрофага та інфікування наступних клітин $\rightarrow$ утворення туберкульозної гранульоми (містить також епітеліоїдні клітини та гігантські клітини Лангерганса), яка оточує зруйновані клітини (вогнища казеозного некрозу). Паралельно розви- 
вається імунологічна відповідь за участю Т-хелперів 1 (Th1) CD4+ лімфоцитів, які активують макрофаги (у тому числі опосередковано через гамма-інтерферон. Ушкодження можуть загоюватися самостійно, шляхом фіброзу. В осіб із порушенням клітинного імунітету спостерігають виділення розріджених казеозних мас, надзвичайно інтенсивне розмноження збудника іутворення порожнин. Допоки розвинеться специфічна імунологічна відповідь, макрофаги, наповнені фагоцитованими мікобактеріями, можуть через лімфатичну систему потрапляти у кров і викликати бактеріємію. У такий спосіб мікобактерії потрапляють до багатьох органів, але затримуються лише у місцях із сприятливими для їх росту умовами. Мікобактерії тривалий час можуть залишатись в організмі людини (латентна туберкульозна інфекція) і, навіть, через багато років спричинити ТБ легень або позалегеневий ТБ. Один хворий на туберкульоз може інфікувати в середньому 10-15 здорових осіб, а якщо він перебуватиме в школі, театрі чи в громадському транспорті, то більше. Це призводить до значного поширення туберкульозу. Ось чому Всесвітня організація охорони здоров'я в 1993 р. проголосила туберкульоз глобальною небезпекою. Останнім часом щороку 24 березня всі країни світу відзначають Всесвітній день боротьби з туберкульозом [1].

Епідемія туберкульозу характеризується як триєдина епідемія. Це означає, що вона містить три складових.

Перша складова включає зростання захворюваності на типовий туберкульоз, тобто такий, який спостерігали в доантибактеріальну еру.

Друга складова епідемії зумовлена хіміорезистентним туберкульозом, який поширюється швидкими темпами і створює велику небезпеку.

Третя складова епідемії зумовлена туберкульозом на тлі синдрому набутого імунодефіциту (СНІДу) та в інфікованих вірусом імунодефіциту людини (ВІЛ). Зважаючи на те, що близько 90,0 \% дорослого населення України інфіковані мікобактеріями туберкульозу, то якщо будь-хто з них заразиться ВІЛ чи захворіє на СНІД, то через зниження імунітету половина ВІЛ-інфікованих і хворі на СНІД захворіють на туберкульоз [4].

Як заражаються туберкульозом? Щоб заразитися і захворіти на туберкульоз має бути 3 компоненти епідемічного процесу:

1) джерело або резервуар туберкульозної інфекції;

2) механізм передачі туберкульозної інфекції;
3) сприйнятливість організму людини чи тварини до туберкульозної інфекції.

Джерелом або резервуаром туберкульозної інфекції може бути хвора людина, більше 55 видів сільськогосподарських тварин, птахів, риб, а також заражені мікобактеріями продукти тваринного і рослинного походження, ґрунт, органічні й неорганічні речовини, в яких живуть, розмножуються чи зберігаються збудники туберкульозу.

Туберкульоз від хворого поширюється повітрянокрапельним (при кашлі, чханні, розмові) та пиловим шляхом (засохлі крапельки мокротиння перетворюються в інфікований пил, який $є$ на підлозі, предметах, в повітрі).

Оскільки немає такого органа людини (тварини), який би не уражався туберкульозом, то залежно від місця ураження мікобактерії туберкульозу (МБТ) можуть виділятися від хворого різними шляхами.

При туберкульозі органів дихання мікобактерії туберкульозу виділяються з харкотинням. Це найчастіший спосіб і становить близько 95,0 \% випадків.

Мікобактерії туберкульозу виділяються з калом при туберкульозі шлунково-кишкового тракту (шлунка, тонкої і товстої кишок, жовчного міхура, розкриття у кишечнику туберкульозних гнояків із очеревини, заочеревинного простору тощо).

Збудники туберкульозу виділяються із сечею чи спермою при туберкульозі сечостатевої системи (нирок, сечового міхура, простати, яєчок, піхви, матки, придатків матки та ін.). При туберкульозному ураженні жіночих статевих органів збудники туберкульозу можуть виділятися із менструальними виділеннями. Можливе виділення мікобактерій з молоком при годуванні дітей матерями, які страждають від туберкульозу молочної залози.

Мікобактерії виділяються зі сльозами при туберкульозі очей, з виразок, нориць - при туберкульозі шкіри, лімфатичних вузлів чи кісток із норицями.

Тварини виділяють мікобактерії туберкульозу із харкотинням, слиною, фекаліями, сечею, заражаючи пасовища. Збудники туберкульозу можуть потрапити у здоровий організм людини при споживанні заражених м'ясо-молочних продуктів (молока, сиру, масла, м'яса тощо).

Поширення туберкульозу шляхом прямого контакту можливе при неохайності хворого, коли його руки забруднені мокротинням, наприклад при рукостисканні, поцілунках. Так найчастіше заражаються діти. 
Непрямий контактно-побутовий шлях передачі туберкульозної інфекції відбувається при контакті людини із одягом, білизною, рушником, посудом, зубною щіткою, носовою хусткою, які заражені виділеннями хворого.

Більшість контактних осіб хворіє на туберкульоз у перші 6-12 місяців від початку контакту, хоча частина членів родини може захворіти й через 9-12 років спільного проживання з хворим.

Збудник туберкульозу. $€$ більше 120 видів мікобактерій. Найнебезпечнішими є мікобактерії туберкульозу людського виду, до яких сприйнятливі людина, мавпи й деякі інші види тварин.

Мікобактерії туберкульозу бичачого виду можуть спричинити хворобу в людини, великої рогатої худоби, свиней, кіз, м'ясоїдних тварин, коней, овець, оленів, маралів, борсуків та ін.

Мікобактерії туберкульозу пташиного виду найнебезпечніші для курей, фазанів, людини, великої рогатої худоби. Свині легко заражаються мікобактеріями туберкульозу людського, бичачого, пташиного, мишачого видів.

Мікобактерії туберкульозу рибного виду уражають акваріумних, річкових, морських, найчастіше коропових, лососевих, анабантових, харацинових та інших риб. Інколи спостерігають масову загибель риб від туберкульозу. В Україні вже є випадки туберкульозу, спричиненого мікобактерією африканською.

Мікобактерії живуть у річковій воді до 5 міс., в ґрунті - 1-2 міс., у фекаліях і на пасовищах - більше 1 року, в молочних продуктах (масло, сир та ін.), що зберігають у холоді - до 10 міс., у пилу - до 3-5 міс. При температурі мінус $23^{\circ} \mathrm{C}$ мікобактерії туберкульозу не гинуть 7 років, а сонце їх вбиває лише від 7-10 хв (пряме) до 2-6 год (розсіяне) [2].

Механізм передачі туберкульозної інфекції - це друга складова епідемічного процесу, це, по суті, шляхи і способи зараження. Варто зазначити, що те місце, де відбувається первинний контакт організму з мікробом, називають вхідними воротами інфекції.

Аерогенний спосіб зараження відбувається при кашлі, чханні, розмові, хворий виділяє заражені збудниками краплини. Вони перебувають у вигляді аерозолю, який швидко висихає. Частина крапель, багатих на мікобактерії, довго перебуває у зваженому стані в повітрі та при вдиханні людиною легко досягає альвеол. Більші краплі осідають, змішуються з пилом, потім пил піднімається і його вдихає людина. Крупний пил осідає у дихальних шляхах, звідки евакуюється мукоциліарними війками, якими вкрита слизова оболонка дихальних шляхів, і при кашлі. Дрібний пил досягає дрібних бронхів, альвеол, де мікобактерії починають розмножуватися.

Аліментарний спосіб зараження можливий при споживанні молока і молокопродуктів від хворих на туберкульоз корів, кіз.

Трансплацентарне зараження плода можливе при заковтуванні плодом інфікованих мікобактеріями навколоплідних вод, через кров, при потраплянні фільтрувальних форм мікобактерій до плода через плаценту, при ушкодженні плаценти під час пологів.

Інші шляхи передачі мікобактерій в здоровий організм: через кон'юнктиву ока, шкіру, статеві органи, мигдалики, при операціях тощо [4].

Сприйнятливість організму людини чи тварини до туберкульозної інфекції - це третя складова епідемічного процесу. Туберкульоз не $\epsilon$ високо заразним захворюванням. При тривалому контакті 3 бактеріовиділювачем інфікується 25,0-50,0 \% людей. Тільки 5,0-15,0 \% інфікованих занедужують на туберкульоз, інші виробляють нестерильний імунітет і залишаються здоровими [3].

Імунітет при туберкульозі називають нестерильний, клітинний, опосередкований Т-лімфоцитами. У сприятливих умовах через 4-8 тижнів після БЦЖвакцинації чи інфікування в організмі з'являється клон навчених Т-лімфоцитів і так формується імунітет.

Загальносистемні симптоми (можуть з'являтися, незалежно від локалізації патологічних змін): підвищення температури тіла, втрата апетиту, зниження маси тіла, нічне потовиділення, погане самопочуття. Аналіз крові: зазвичай результат у нормі, іноді лейкопенія або лейкоцитоз, анемія, пришвидшена ШОЕ, інколи - гіпонатріємія і гіперкальціємія.

Суб'єктивні симптоми: хронічний кашель (спочатку сухий, у подальшому - вологий з відхаркуванням слизистого або гнійного секрету), інколи - кровохаркання, при деяких формах (зокрема при казеозній пневмонії, міліарному ТБ легень або фіброзно-кавернозному ТБ) може розвинутись дихальна недостатність.

Об'єктивні симптоми: у хворих із занедбаними змінами прояви, характерні для інфільтрату або каверн у легенях.

Допоміжні дослідження:

1) рентгенографія (РГ) грудної клітки - при первинному ТБ (захворювання безпосередньо після інфікування) спостерігають консолідацію, найчастіше у середніх і нижніх ділянках легеневих полів, збільшення 
прикореневих та паратрахеальних лімфатичних вузлів. При вторинному ТБ спостерігають консолідацію (різного ступеня інтенсивності; на занедбаних стадіях - часто каверни, що мають вигляд просвітлень, обмежених тіньовою обвідкою), найчастіше у верхівкових і задніх сегментах верхніх часток легень, а також у верхніх сегментах нижніх часток. Інколи інфільтративні зміни мають вигляд тіней округлої форми, що формуються внаслідок інкапсуляції казеозних мас (так звана туберкульома або казеома), при імуносупресивних станах можуть спостерігати нетипові зміни.

2) бактеріологічні дослідження;

3) туберкулінова проба - внутрішньошкірне введення туберкуліну, оцінка діаметра інфільтрату через 48-72 год; позитивна проба (папула $\geq 5$ мм) свідчить про інфікування ТБ (не дозволяє віддиференціювати інфікування та захворювання), може також спостерігатись після вакцинації БЦЖ, інколи після контакту 3 нетуберкульозними мікобактеріями;

4) тести, що ґрунтуються на виділенні лімфоцитами гамма-інтерферону - більш специфічні, ніж туберкулінова проба, вакцинація БЦЖ не впливає на результат.

Окремі форми туберкульозу легень:

1) міліарний;

2) казеозне запалення легень;

3) фібринозно-кавернозний ТБ.

Позалегеневий туберкульоз:

1. ТБ плеври: зазвичай розвивається через кілька місяців після первинного інфікування. Приблизно у 30,0 \% випадків позитивне дослідження рідини на наявність МБТ.

2. ТБ лімфатичних вузлів: спостерігають найчастіше у дітей та осіб молодого віку. Приблизно в 50,0% випадків наявні також зміни у легенях.

3. ТБ сечостатевої системи.

4. ТБ кісток і суглобів: у країнах із низькою поширеністю ТБ, переважно в осіб похилого віку, зазвичай має тривалий латентний період.

5. ТБ центральної нервової системи: спостерігають частіше в дітей у формі туберкульозного менінгіту або туберкульоми.

6. ТБ травної системи: спостерігають рідко.

7. Інші форми позалегеневого ТБ: перикарда, шкіри, великих судин або кісткового мозку - спостерігають дуже рідко, однак пам'ятайте про те, що ТБ може уражати кожний орган [5].

\section{Загальні принципи лікування:}

1) схеми лікування повинні включати в інтенсивній

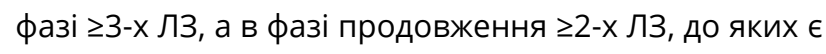
ймовірно чутливими виявлені у хворого МБТ;
2) до схеми лікування, яка виявилася неефективною, ніколи не потрібно додавати по одному новому препарату;

3) лікування повинно проходити під наглядом, особливо у випадку значної ймовірності недотримання хворим рекомендацій та у випадках, значущих для громадського здоров'я (резистентність до ЛЗ, рецидив захворювання);

4) на початку лікування про кожен випадок туберкульозу має бути повідомлено до санітарно-епідеміологічної станції (захворюваність на ТБ реєструють);

5) перед початком лікування визначте активність печінкових ферментів, рівень білірубіну, сечовини, креатиніну і сечової кислоти у сироватці крові, рівень тромбоцитів у крові, у разі призначення етамбутолу (Е) скеруйте хворого на консультацію до окуліста, необхідно продумати обстеження на ВІЛ-інфекцію або інші причини імуносупресії, оцініть ймовірність резистентності до ЛЗ та готовність пацієнта до співпраці;

6) проводьте моніторинг небажаних ефектів та взаємодії ЛЗ [4].

Ускладнення: пневмоторакс, емпієма плеври, фіброз плеври, легенева кровотеча, амілоїдоз.

\section{Профілактика}

1. Рання діагностика і лікування хворих на ТБ; першу фазу лікування пацієнтів, які виділяють паличку мікобактерію ТБ, проводять в умовах стаціонару.

2. Профілактика внутрішньолікарняних інфекцій:

1) до моменту виключення діагнозу ТБ або до ерадикації мікобактерій пацієнти повинні залишатися в ізоляторах;

2) часте провітрювання або адекватна вентиляція палат (обмін повітря 6 × на год у старих приміщеннях і 20 × год у нових будинках, виведення повітря за межі будинку або відповідна фільтрація, підтримка негативного тиску в приміщенні) та опромінення УФ-лампами;

3) пацієнти, які виходять з відділення, персонал, а також відвідувачі мають носити маски (оптимально з фільтром НЕРА);

4) не використовувати для прибирання пилососи, вентилятори; вологе прибирання приміщення та дезінфекція підлоги, а також поверхонь відповідними мікобактеріоцидними засобами.

3. Щеплення від туберкульозу (БЦЖ): підлягають усі новонароджені діти, які не мають до цього протипоказань, - на 3-5-ту добу життя дитини (не раніше 48-ї години після народження); ревакцинації проти туберкульозу підлягають діти віком 7 років, не інфіковані мікобактеріями туберкульозу та з негативним ре- 
зультатом проби Манту. Протипоказання: алергія на складник вакцини, гарячка, генералізований дерматит, уроджені імунні порушення, приймання ЛЗ, які порушують імунітет, злоякісні новоутворення, ВІЛ-інфекція (вакцинація новонароджених, народжених ВІЛ-інфікованими жінками, - після консультації), приймання протитуберкульозних Лз.

4. Особи, які контактували з хворим на ТБ, особливо, з бактеріовиділенням, повинні бути обстежені на предмет туберкульозу (наявність клінічних симптомів, РГ грудної клітки, туберкулінодіагностика).

5. Профілактичне лікування (дозування ЛЗ, як при лікуванні активного ТБ): ізоніазид (INH) $1 \times$ на день впродовж 6-ти або 9-ти міс., рифампіцин (RMP) 1 × на день впродовж 3-4 міс. (застосування RMP off-label), RMP з INH 1 × на день впродовж 3-4 міс., рифапентин та INH $1 \times$ на тиж. упродовж 3-х міс.). Під час лікування контроль щомісяця; в осіб із захворюванням печінки, які регулярно вживають алкоголь, або ВІЛ-інфікованих, осіб віком >35-ти років, вагітних жінок

\section{СПИСОК ЛІТЕРАТУРИ}

1. Фещенко Ю. І. Погляд на проблему боротьби з туберкульозом в Україні [Текст] / Ю. І. Фещенко // Український пульмонологічний журнал. - 2016. - № 3. - С. 5-10.

2. Устінов О. В. МОЗ України повідомляє про розроблення концепції програми протидії туберкульозу [Електронний ресурс] / О. В. Устінов // Український медичний часопис. - 2017. - Режим доступу : http://www. umj.com.ua/article/104403/ moz-ukrayini-povidomlyaye-porozroblennya-kontseptsiyi-programi-protidiyi-tuberkulozu.

3. Професійні інфекційні хвороби [Текст] / Ю. І. Кундієв, М. А. Андрейчин, А. М. Нагорна, Д. В. Варивончик. - К. : ВД «Авіцена», 2014. - 529 с. або жінок <3-х міс. після пологів - контроль активності АСТ і АЛТ та рівня білірубіну в сироватці крові.

Висновки. Дослідженнями визначено, що епідемія туберкульозу в Україні, яка розпочалась в 1995 р., на сьогодні перебуває в активній стадії і характеризується подальшим зростанням нових випадків та рівнів захворюваності на туберкульоз, наявністю значної кількості хворих на занедбані форми патології та масивне бактеріовиділення, із високим рівнем хіміорезистентності мікобактерій туберкульозу. На туберкульоз в Україні найчастіше (в 2,4 раза) хворіють чоловіки (70,8 \%), ніж жінки (29,2 \%). Максимум захворюваності на туберкульоз серед чоловіків спостерігали у віці 25-54 роки (71,5 \%), а серед жінок 25-44 роки (46,4 \%). В Україні на законодавчому та нормативно-правовому рівнях створені сприятливі умови, спрямовані на профілактику та боротьбу із туберкульозом на робочому місці, які в цілому відповідають вимогам ВООЗ та моП.

4. Хіміорезистентний туберкульоз: поширеність та профіль стійкості мікобактерій туберкульозу до антимікобактеріальних препаратів [Текст] / В. М. Мельник, І. О. Новожилова, В. Г. Матусевич та ін. // Український пульмонологічний журнал. - 2013. - № 3. - С. 19-23.

5. Lan Z. Treatment of human disease due toMycobacterium bovis: a systematic review [Text] / Z. Lan, M. Bastos, D. Menzies // European Respiratory Journal. - 2016. - Vol. 48, Issue 5. - P. 1500-1503. doi: 10.1183/13993003.00629-2016

Отримано 02.09.19 